\title{
Assessment of water quality in Shitalakhya river insights from phytoplankton and nutrient regimes
}

\author{
MD. JAHANGIR SARKER*, SUMON ADIKARI AND JESMIN AKTER ${ }^{1}$ \\ Department of Fisheries and Marine Science, \\ Noakhali Science and Technology University, Noakhali 3814, Bangladesh \\ ${ }^{1}$ Upazilla Fisheries Officer, Department of Fisheries, Bangladesh \\ *Email: mjsarker@nstu.edu.bd
}

\begin{abstract}
The present study assessed the water quality parameter insights from phytoplankton and nutrient regimes of the Shitalakhya River based on three sampling stations. The ranges of water temperature, transparency, dissolved oxygen, $\mathrm{pH}$, TDS, phosphate-phosphorus, nitrite-nitrogen, nitrate-nitrogen, and silicate were $27.86 \pm 0.249{ }^{\circ} \mathrm{C}$ to $29.83 \pm 0.612{ }^{\circ} \mathrm{C}, 42.33 \pm 0.471$ to $31.33 \pm 0.942 \mathrm{~cm}, 6.35 \pm 0.232$ to $5.88 \pm 0.066 \mathrm{mg} / \mathrm{L}, 7.62 \pm 0.008$ to $7.52 \pm 0.018,63.33 \pm 4.714$ to $40 \pm 8.164 \mathrm{mg} / \mathrm{L}, \quad 0.52 \pm 0.020$ to $0.34 \pm 0.016 \mathrm{mg} / \mathrm{L}, 0.06 \pm 0.012$ to $0.01 \pm 0.004 \mathrm{mg} / \mathrm{L}, 0.12 \pm 0.008$ to $0.05 \pm 0.004 \mathrm{mg} / \mathrm{L}$, and $0.12 \pm 0.004$ to $0.07 \pm 0.001 \mathrm{mg} / \mathrm{L}$ respectively. The values of transparency, TDS, nitrite, nitrate, and silicate varied significantly while other parameters showed non-significant $(p>0.05)$ among three stations. The results also indicated the presence of 27 genera belonging to five major groups- Bacillariophyceae (9), Chlorophyceae (8), Euglenophyceae (5), Dinophyceae (3), and Cyanophyceae (2). The dominant phytoplankton group was the Bacillariophyceae (38\%), followed in order by Chlorophyceae (26\%), Euglenophyceae (19\%), Dinophyceae (12\%), and Cyanophyceae (5\%). Shannon-Weiner species diversity index $\left(\mathrm{H}^{\prime}\right)$ ranged from 2.31 to 2.99 (phytoplankton) indicating the water body is moderately polluted. Overall, maximum density $\left(46.66 \times 10^{3}\right.$ cells $\left.\mathrm{L}^{-1}\right)$ of phytoplankton was observed at $\mathrm{S}_{2}$ followed by $\mathrm{S}_{3}\left(35.23 \times 10^{3}\right.$ cells $\left.\mathrm{L}^{-1}\right)$ and $\mathrm{S}_{1}$ $\left(20.95 \times 10^{3}\right.$ cells $\left.\mathrm{L}^{-1}\right)$. The fluctuation of the physico-chemical parameters and phytoplankton density of the river could be attributed to the high influx of nutrients into the river as a result of discharging nutrient reach water from. Monitoring of these activities within the river and education on the wise use of the water is recommended.

Keywords: Physico-chemical parameters, Phytoplankton, Nutrients, Shitalakhya River
\end{abstract}

\section{Introduction}

Bangladesh is a land of rivers whose fresh water and saltwater area occupy about $68,644.8$ ha and 40,250 square km, respectively (Zafar 1986, Kabir et al. 2019). The Shitalakhya is a branch of the Brahmaputra which has changed its course at least twice in the Bangladesh region in the fairly recent past, indirectly affecting the flow of water in the Shitalakhya. The river is about $110 \mathrm{~km}$ long (Murshed et al. 2012).

Phytoplankton is a key component of the river biota in general because it forms the base of the pyramid of productivity (Usman 2016). Physico-chemical and biotic characteristics of water are interrelated and often driven by the surrounding land uses that determine the quality of water at point sources that enter the freshwater streams (Fonge et al. 2015). Physicochemical parameters and nutrients in water play a significant role in the distributional pattern and species composition of aquatic phytoplankton (Negi and Vishal 2015). The eutrophication of water bodies accelerated by human activities creates the need for various activities to be undertaken to restore good water quality (Kozak et al. 2012). The Physico-chemical properties will also help 
in the identification of sources of pollution, for conducting further investigations on the ecobiological impacts, and also for initiating necessary steps for remedial actions in case of polluted water bodies. Chemical, physical, and biological contaminants from anthropogenic activities pollute surface water.

River pollution is a matter of concern all over the world (Noori et al. 2010). Most probably, on both aquatic biota and human being the effects of industrialization are in the state of beggar description. Shitalakhya is one of the main rivers of the capital city of Bangladesh and has become the effectors of development providing freshwater supply, fish production, transportation, and waste assimilation provision along with a wide array of recreation and tourism options. A preliminary study on the physico-chemical aspects and phytoplankton abundance from a part of the Shitalakhya River receiving pharmaceutical effluents has been done by Begum and Khanam (2009). A factual report of the water quality of the Shitalakhya river is also available (Islam and Huda 2016). The present study area was located close to the Ghorasal Fertilizer factory in the Shitalakhya Riverine area. Effluents of the Ghorasal Fertilizer factory are discharging into the river water in that area. So there might be an effect of industrial effluent on water quality parameters and phytoplankton abundance. So, the study on physico-chemical parameters, phytoplankton abundance in Shitalakhya River is very important and effective in the re-evaluation of the uses and stability of the Shitalakhya River of Bangladesh.

The study will give field evidence concerning the effect of physical and chemical water quality on the phytoplankton abundance and the phytoplankton structure in Shitalakhya River so that it could help speed up the concept of technological development effort in managing the water quality and the phytoplankton abundance development in the most favorable condition and as an effort of sustainable aquatic resources management. The knowledge of phytoplankton in the aquatic environments could be useful in predicting the movement of herbivore fishes. Therefore, the present investigation was carried out on the surface plankton's population to determine physico-chemical parameters and create a relationship between phytoplankton abundance with physico-chemical parameters of Shitalakhya river water.

\section{Materials and Methods}

Study area and sample collection:: The present study was conducted in October 2019. A total of three sampling stations namely S1, S2, and S3 from Palash Upazila were selected on river Shitalakhya under Narsinghdi district for sample collection and analysis of water (Fig. 1).

For phytoplankton study, $1 \mathrm{~L}$ of water sample was collected from surface water of each station from 8 am to 11 am with three replicates and kept into plastic vials with $2 \%$ Lugol's iodine. The sampled water was transferred to measuring cylinders and left to settle down the phytoplankton. Water from the upper layer was removed and the samples were concentrated to $10 \mathrm{ml}$ and used for microscopic examination. From each sampling station, another 1 liter of water sample was collected, filtered through glass fiber filter paper (Whatman GF/C), and immediately kept in the freezer for nutrient analysis. The analysis was performed by using a spectrophotometer (HACH water analysis, model DR 2700). 
Water quality measurement: Water temperature, $\mathrm{pH}$, and $\mathrm{DO}$ were measured directly from the collected water of three stations using digital water multi parameters (model: H198194). TDS was measured by a digital TDS meter. Water transparency was measured by a Secchi disc.

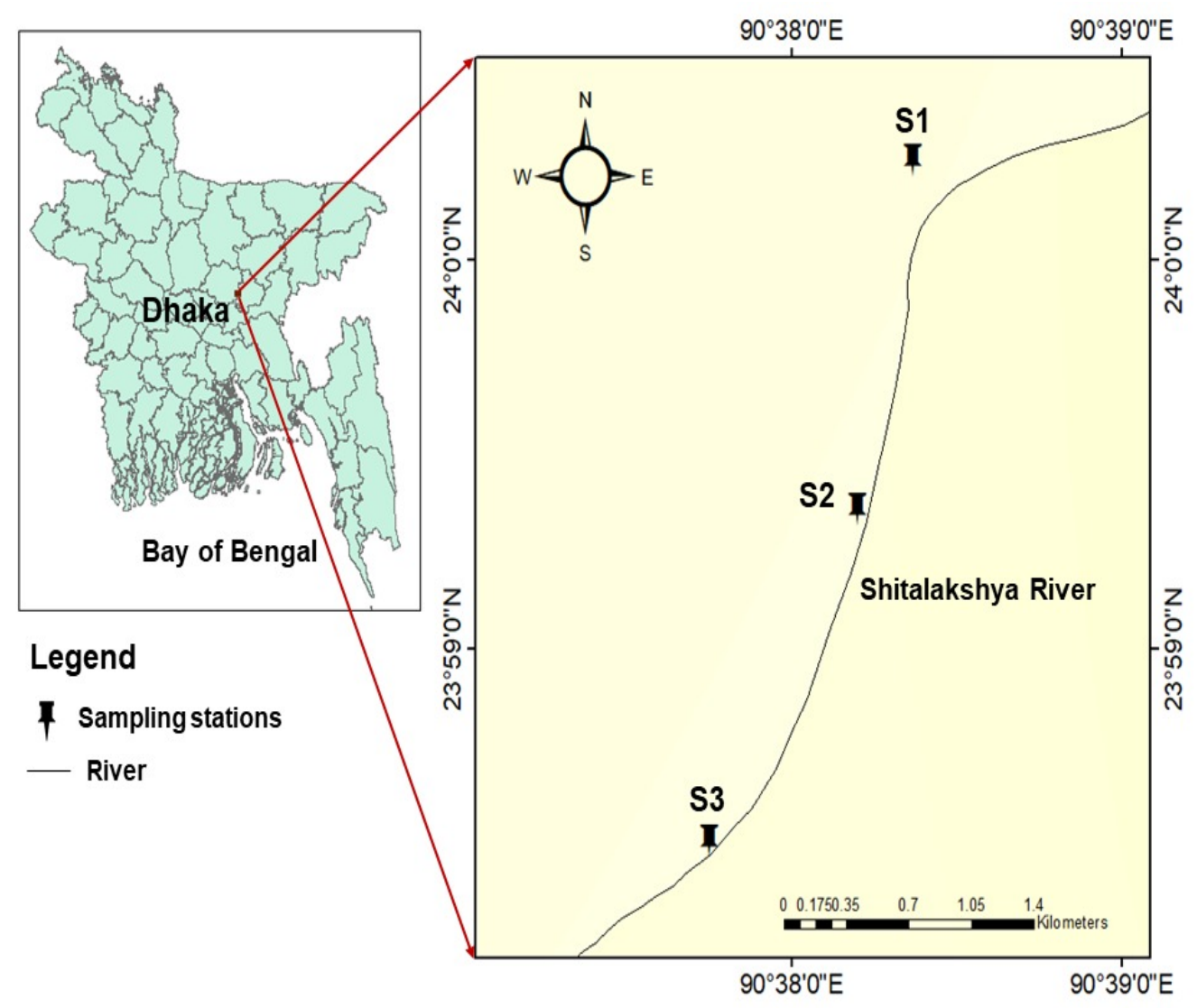

Fig. 1. Location of the sampling stations in Shitalakhya River, Narsinghdi, Bangladesh.

Identification and enumeration of phytoplankton: Identification of phytoplankton up to genera level was performed following Bellinger and Sigiee (2015) under a compound microscope (Luminous Stereoscopic Microscope, Model: SL 2240). The phytoplankton genus that was found in each three replicates of the station was denoted as very common (high), two replicates denoted as common (medium) and one replicates denoted as rare (low) abundance.

Enumeration of the density of phytoplankton was done using an S-R cell and the abundance was expressed as cells $\mathrm{L}^{-1} .1 \mathrm{ml}$ sample was put in the $\mathrm{S}-\mathrm{R}$ cell and left $5 \mathrm{~min}$ to allow phytoplankton to settle down and the cells in 20 randomly selected fields were counted. Plankton density was calculated using the formula (Pitchaikani and Lipton 2016): $\mathrm{N}=(\mathrm{P} \times \mathrm{C} \times 1000) / \mathrm{L}$ 
where, $\mathrm{N}=$ the total number of phytoplankton per liters of sample water; $\mathrm{P}=$ the average number of phytoplankton counted in $1 \mathrm{ml}$ of sample water; $\mathrm{C}=$ the volume of concentrate sample water; $\mathrm{L}=$ the total volume of the sample water $(1 \mathrm{~L})$.

Diversity indices: Shannon-Weiner diversity index $\left(\mathrm{H}^{\prime}\right)$ (Shannon and Weiner, 1949), Simpson's dominance index (D) (Simpson, 1949), Margalef richness index (d) (Margalef 1958) and Pielou's evenness index ( $\mathrm{J}^{\prime}$ ) (Pielou 1977) were calculated according to following equations:

$$
\begin{aligned}
& \mathrm{H}^{\prime}=-\sum[\mathrm{Pi} \times \log (\mathrm{Pi})] \\
& \mathrm{D}=\sum(\mathrm{pi})^{2} \\
& \mathrm{~d}=(\mathrm{S}-1) / \log \mathrm{N} \\
& \mathrm{J}^{\prime}=\mathrm{H}^{\prime} / \log (\mathrm{S})
\end{aligned}
$$

where ' $\mathrm{Pi}$ ' is the proportion of the individuals belonging to the ' $\mathrm{i}^{\text {'th }}$ genus, Simpson's index of diversity $=1 / \mathrm{D}, \mathrm{N}=$ total number of individuals, and $\mathrm{S}=$ total number of the genus.

Statistical analysis: One-way analysis of variance (ANOVA) was done to examine significant differences among the physico-chemical parameters.

\section{Results and Discussion}

Water temperature: Temperature has a direct influence on the growth, abundance, distributions of phytoplankton in the water body. The lowest mean water temperature $\left(27.86 \pm 0.249^{\circ} \mathrm{C}\right)$ was recorded at $S_{1}$ and the highest $\left(29.83 \pm 0.612^{\circ} \mathrm{C}\right)$ was recorded at $S_{2}$ however, no significant difference $(p>0.05)$ was observed among temperature of the three stations (Table I). The standard value of water temperature in the river is $20^{\circ} \mathrm{C}-30^{\circ} \mathrm{C}$ (ECR 1997), which shows similarity with the present findings, and the water temperature was found within the acceptable ranges for phytoplankton growth.

Transparency: The water transparency of the studied sites ranged from $31.33 \pm 0.942 \mathrm{~cm}$ to $42.33 \pm 0.471 \mathrm{~cm}$ with significant variations among the sites $(p<0.05)$ (Table I). According to Wahab et al. (1994), the transparency of productive water bodies should be $40 \mathrm{~cm}$ or less. The lower values of Secchi disc reading were observed $(31.33 \pm 0.942 \mathrm{~cm})$ in the present study might be due to various human activities, domestic sewage, and sludge wash from the adjoining areas.

Dissolved oxygen (DO): Dissolved oxygen is used as an important indicator of water quality which evaluates the freshness of a river (Fakayode 2005) and the level of organic pollution in the water body (Wetzel and Likens 2006). At the studied sites, DO range from $6.35 \pm 0.232$ $\mathrm{mg} / \mathrm{L}$ to $5.88 \pm 0.066 \mathrm{mg} / \mathrm{L}$ with no significant difference $(p>0.05)$ among the three stations (Table I).

pH and Total Dissolved Solids (TDS): In the Shitalakhya river, $\mathrm{pH}$ fluctuated between $7.62 \pm 0.008$ and $7.52 \pm 0.018)$. The maximum value of $\mathrm{pH}(7.62 \pm 0.008)$ was found at $\mathrm{S}_{3}$, while the minimum $(7.52 \pm 0.018)$ was found at $\mathrm{S}_{1}$ (Table I). The standard value of water $\mathrm{pH}$ for fish ranges from 6.5-8.5 (ECR 1997). TDS concentration was found to vary between $40 \pm 8.164$ $\mathrm{mg} / \mathrm{L}$ and $63.33 \pm 4.714 \mathrm{mg} / \mathrm{L}$ in the present study showing significant differences $(p<0.05)$ among the three stations (Table I). TDS concentrations have been recommended by the USEPA 
up to $500 \mathrm{mg} / \mathrm{L}$ (EPA 1997) as useful indicators of water quality and are important measurements for several reasons. Increased TDS are indicators of erosion.

Phosphate: Phosphate stimulates the growth of plankton and aquatic plants which provide food for the larger organism in the aquatic food chain. During the present study, the value of $\mathrm{PO}_{4}$ was found to range between $0.52 \pm 0.020 \mathrm{mg} / \mathrm{L}$ and $0.34 \pm 0.016 \mathrm{mg} / \mathrm{L}$ (Table I). Ahmed et al. (2010) recorded 0.12-4.94 mg/L $\mathrm{PO}_{4-} \mathrm{P}$ from the Karnafuli river water. Alam et al. (2007) worked on the river water quality and stated that the effluent and discharge area has a low concentration of phosphate.

Nitrate and Nitrite nitrogen: The $\mathrm{NO}_{3}{ }^{-}$the range of present finding was $0.12 \pm 0.008 \mathrm{mg} / \mathrm{L}$ to $0.05 \pm 0.004 \mathrm{mg} / \mathrm{L}$ with significant difference $(p<0.05)$ among three stations (Table I). Ahmed et al. (2010) estimated $(0.00-0.87 \mathrm{mg} / \mathrm{L})$ nitrate values in the Halda river and $0.00-1.63 \mathrm{mg} / \mathrm{L}$ in the Karnafuli river water. Bellos et al. (2004) found a higher correlation of nitrate concentrations with low flow in a river. Nitrate $\left(\mathrm{NO}_{3}{ }^{-}\right)$followed a spatial trend of high concentration at $S_{2}$. The source of nitrate in the studied area might be nearby aquaculture effluents; urban disposal and industrial wastewater. The maximum value of nitrite $(0.06 \pm 0.012$ $\mathrm{mg} / \mathrm{L})$ was found in $\mathrm{S}_{2}$, while the minimum value $(0.01 \pm 0.004 \mathrm{mg} / \mathrm{L})$ was found in $\mathrm{S}_{1}$ showing significant difference $(p<0.05)$ among three stations (Table I). Ferdous et al. (2012) recorded 0.23 to $0.78 \mathrm{mg} / \mathrm{L} \mathrm{NO}_{2}^{-}$from the Buriganga River.

Silicate: The maximum value of silicate $(0.12 \pm 0.004 \mathrm{mg} / \mathrm{L})$ was found in $\mathrm{S}_{2}$, while the minimum value $(0.07 \pm 0.001 \mathrm{mg} / \mathrm{L})$ was found in $\mathrm{S}_{1}$ with significant differences $(p<0.05)$ among three stations (Table I). According to Ahamad et al. (2003) it was found within the range of silicate $1.1015 \mathrm{mg} / \mathrm{L}$ to $0.06 \mathrm{mg} / \mathrm{L}$ in river water and these higher concentrations of $\mathrm{SiO}^{4-}$

Table I. Mean values of water quality parameters recorded from different stations

\begin{tabular}{lcccc}
\hline Parameters & \multicolumn{2}{c}{ Stations } & \multicolumn{2}{c}{ Level of } \\
& Station 1 & Station 2 & Station 3 & significance \\
\hline Temperature $\left({ }^{\circ} \mathrm{C}\right)$ & $27.86 \pm 0.249$ & $29.83 \pm 0.612$ & $28.8 \pm 0.326$ & $\mathrm{NS}$ \\
Transparency $(\mathrm{cm})$ & $42.33 \pm 0.471$ & $31.33 \pm 0.942$ & $37.33 \pm 0.942$ & $*$ \\
pH & $7.52 \pm 0.018$ & $7.56 \pm 0.016$ & $7.62 \pm 0.008$ & $\mathrm{NS}$ \\
DO $(\mathrm{mg} / \mathrm{l})$ & $6.35 \pm 0.232$ & $5.88 \pm 0.066$ & $5.98 \pm 0.026$ & $\mathrm{NS}$ \\
TDS(mg/l) & $40 \pm 8.164$ & $63.33 \pm 4.714$ & $60 \pm 8.164$ & $*$ \\
Phosphate $(\mathrm{mg} / \mathrm{l})$ & $0.34 \pm 0.016$ & $0.52 \pm 0.020$ & $0.44 \pm 0.016$ & $\mathrm{NS}$ \\
Nitrite $(\mathrm{mg} / \mathrm{l})$ & $0.01 \pm 0.004$ & $0.06 \pm 0.012$ & $0.04 \pm 0.008$ & $*$ \\
Nitrate $(\mathrm{mg} / \mathrm{l})$ & $0.05 \pm 0.004$ & $0.12 \pm 0.008$ & $0.08 \pm 0.009$ & $*$ \\
Silicate $(\mathrm{mg} / \mathrm{l})$ & $0.07 \pm 0.001$ & $0.12 \pm 0.004$ & $0.09 \pm 0.001$ & $*$ \\
\hline
\end{tabular}

Note: *Significant difference at $5 \%$ significance level, NS $=$ Not significant.

may result from the shrimp-farm effluents and nutrient export from the harbor that enriched the coastal water with nutrient. Often; $\mathrm{SiO}^{4-}$ acts as a limiting nutrient for diatom growth; and it could therefore control replacement of diatoms by dinoflagellates in conditions of Si deficiency; which means that $\mathrm{SiO}_{4}{ }^{4-}$ can play an important role in phytoplankton community-structure changes. 
Phytoplankton abundance and composition: The phytoplankton in the Shitalakhya river was represented by five Classes such as Bacillariophyceae, Chlorophyceae, Euglenophyceae, Dinophyceae, and Cyanophyceae (Table II). Bacillariophyceae was recorded as the most dominant group which contributed $38 \%$ to the total phytoplankton population. A total of 9 species of Bacillariophyceae were recorded. The dominant species were Cyclotella spp., Caloneis spp., Coscinodiscus spp., Gomphonema spp., Nitzschia spp., Navicula spp., Pinnularia spp., Stephanodiscus spp. and Synedra spp. The density of Bacillariophyceae was found to be maximum $\left(17.14 \times 103\right.$ cells $\left.\mathrm{L}^{-1}\right)$ at $\mathrm{S}_{2}$ and minimum $\left(8.56 \times 10^{3}\right.$ cells $\left.\mathrm{L}^{-1}\right)$ at $\mathrm{S}_{1}$ during the investigation (Fig. 2). Chlorophyceae was the second most abundant group of phytoplankton recorded during the present study was Chlorophyceae contributing $26 \%$ of the total phytoplankton population. A total of 8 species of Chlorophyceae were recorded from the Shitalakhya River. Actinastrum spp., Botryococcus spp., Chlamydomonas spp., Golenkinia spp., Haematococcus spp., Pleurococus spp., Pediastrum spp. and Scendesmus spp. were found to be the dominant species. Maximum $\left(12.37 \times 10^{3}\right.$ cells $\left.\mathrm{L}^{-1}\right)$ density was recorded at $\mathrm{S}_{2}$ followed by moderate $\left(8.57 \times 10^{3}\right.$ cells $\left.\mathrm{L}^{-1}\right)$ density at $\mathrm{S}_{3}$ and minimum $\left(5.71 \times 10^{3}\right.$ cells $\left.\mathrm{L}^{-1}\right)$ at $\mathrm{S}_{1}$ (Fig. 2$)$.

Euglenophyceae was ranked third in respect of both abundance and number of genera It contributes $19 \%$ of the total phytoplankton population (Table II). A total of 5 species of Chlorophyceae were recorded from the Shitalakhya River. Euglena spp., Phacus spp., Trachelomonas spp., Lepocinclis spp. and Strombomonas spp. were found to be the dominant species. Maximum $\left(8.57 \times 10^{3}\right.$ cells $\left.\mathrm{L}^{-1}\right)$ density was recorded at $\mathrm{S}_{2}$ followed by moderate $\left(7.2 \times 10^{3}\right.$ cells $\left.L^{-1}\right)$ density at $S_{3}$ and minimum $\left(3.80 \times 10^{3}\right.$ cells $\left.L^{-1}\right)$ at $S_{1}$ (Fig. 2). Dinophyceae was ranked fourth in respect of both abundance and number of genera (Table II). It contributes $12 \%$ of the total phytoplankton population. A total of 3 species of Dinophyceae were recorded from the Shitalakhya River. Ceratium spp., Peridinium spp. and Peridinopsis spp. were found to be the dominant species. Maximum $\left(5.70 \times 10^{3}\right.$ cells $\left.\mathrm{L}^{-1}\right)$ density was recorded at $\mathrm{S}_{2}$ followed by moderate $\left(3.80 \times 10^{3}\right.$ cells $\left.\mathrm{L}^{-1}\right)$ density at $\mathrm{S}_{3}$ and minimum $\left(2.85 \times 10^{3}\right.$ cells $\left.\mathrm{L}^{-1}\right)$ at $\mathrm{S}_{1}$ (Fig. 2$)$. Cyanophyceae contributed only $5 \%$ to the total phytoplankton population of the Shitalakhya River. Maximum density $\left(3.32 \times 10^{3}\right.$ cells $\left.\mathrm{L}^{-1}\right)$ of Cyanophyceae was recorded at $\mathrm{S}_{3}$ and minimum $\left(2.85 \times 10^{3}\right.$ cells $\left.\mathrm{L}^{-1}\right)$ at $\mathrm{S}_{2}$ in the Shitalakhya River (Fig. 2). A total of two species Anabaena spp. and Microcystis spp. were recorded.

The dominance of Bacillariophyceae (Diatoms) in the present study agrees with the reports of Onyema (2008), Esenowo and Ugwumba (2010) as diatoms are the most obvious representatives of the phytoplankton in rivers, seas, and lakes. Onyema et al. (2003) reported the presence of some phytoplankton species such as Navicula spp., Nitzchiz spp., Anabana spp., and Synedra spp. as good indicators of organic pollution in any aquatic ecosystem. Thus, lower percentage abundance of Navicula and Anabaena species in the Shialakhya River may suggest a mild level of organic pollution. This may also be a clear indication that the river may be undergoing gradual pollution stress as a result of anthropogenic activities such as effluents from laundry, bathing, and fertilizer industry which may pose a severe negative impact on the water parameters.

Phytoplankton diversity indices: Shannon-Wiener diversity index can be used as the pollution index in diatom communities. Hendley (1977) put forward the following scale: of $0-1$ for high pollution, of 1-3 for moderate pollution, and 3-4 for incipient pollution. In the present study, 
the highest Shannon-Wiener diversity index was found to be 2.99 at station 2 and a relatively low value (2.31) was observed at station 1 (Table III). This means that station 2 has more abundance of phytoplankton than the other stations. Dash (1996) reported that the higher the Shannon-Wiener index $\left(\mathrm{H}^{\prime}\right)$ in Odisha lake, the greater the planktonic diversity. It can be said that the diversity index values of plankton are within the range of 1-3 indicates the moderately polluted environment of the Shitalakhya River from the present study. Simpson diversity index varied from 0.89 (station 1) to 0.93 (station 2) during the present study (Table III). This indicates that the values are approaching 1 , signifying that sites have high relative diversity due to their supporting surrounding components.

Table II. Micro-floral profile of Shitaakhya River (generic level)

\begin{tabular}{|c|c|c|c|c|}
\hline Phytoplankton & Station 1 & Station 2 & Station 3 & Class-wise abundance (\%) \\
\hline Class: Bacillariophyceae & & & & 38 \\
\hline Cyclotella spp. & + & +++ & ++ & \\
\hline Caloneis spp. & ++ & ++ & +++ & \\
\hline Coscinodiscus spp. & + & ++ & - & \\
\hline Gomphonema spp. & - & + & - & \\
\hline Nitzschia spp. & +++ & ++ & + & \\
\hline Navicula spp. & + & ++ & ++ & \\
\hline Pinnularia spp. & - & + & - & \\
\hline Stephanodiscus spp. & - & ++ & ++ & \\
\hline Synedra spp. & - & + & ++ & \\
\hline Class: Chlorophyceae & & & & 26 \\
\hline Actinastrum spp. & ++ & ++ & ++ & \\
\hline Botryococcus spp. & + & +++ & + & \\
\hline Chlamydomonas spp. & ++ & + & + & \\
\hline Golenkinia spp. & - & + & - & \\
\hline Haematococcus spp. & - & + & - & \\
\hline Pleurococus spp. & + & ++ & ++ & \\
\hline Pediastrum spp. & - & + & ++ & \\
\hline Scendesmus spp. & - & + & - & \\
\hline Class: Euglenophyceae & & & & 19 \\
\hline Euglena spp. & ++ & +++ & + & \\
\hline Phacus spp. & + & + & + & \\
\hline Trachelomonas spp. & - & + & ++ & \\
\hline Lepocinclis spp. & + & ++ & + & \\
\hline Strombomonas spp. & - & ++ & - & \\
\hline Class: Dinophyceae & & & & 12 \\
\hline Ceratium spp. & + & + & ++ & \\
\hline Peridinium spp. & + & ++ & ++ & \\
\hline Peridinopsis spp. & - & ++ & - & \\
\hline Class: Cyanophyceae & & & & 5 \\
\hline Anabaena spp. & - & ++ & ++ & \\
\hline Microcystis spp. & - & + & + & \\
\hline
\end{tabular}




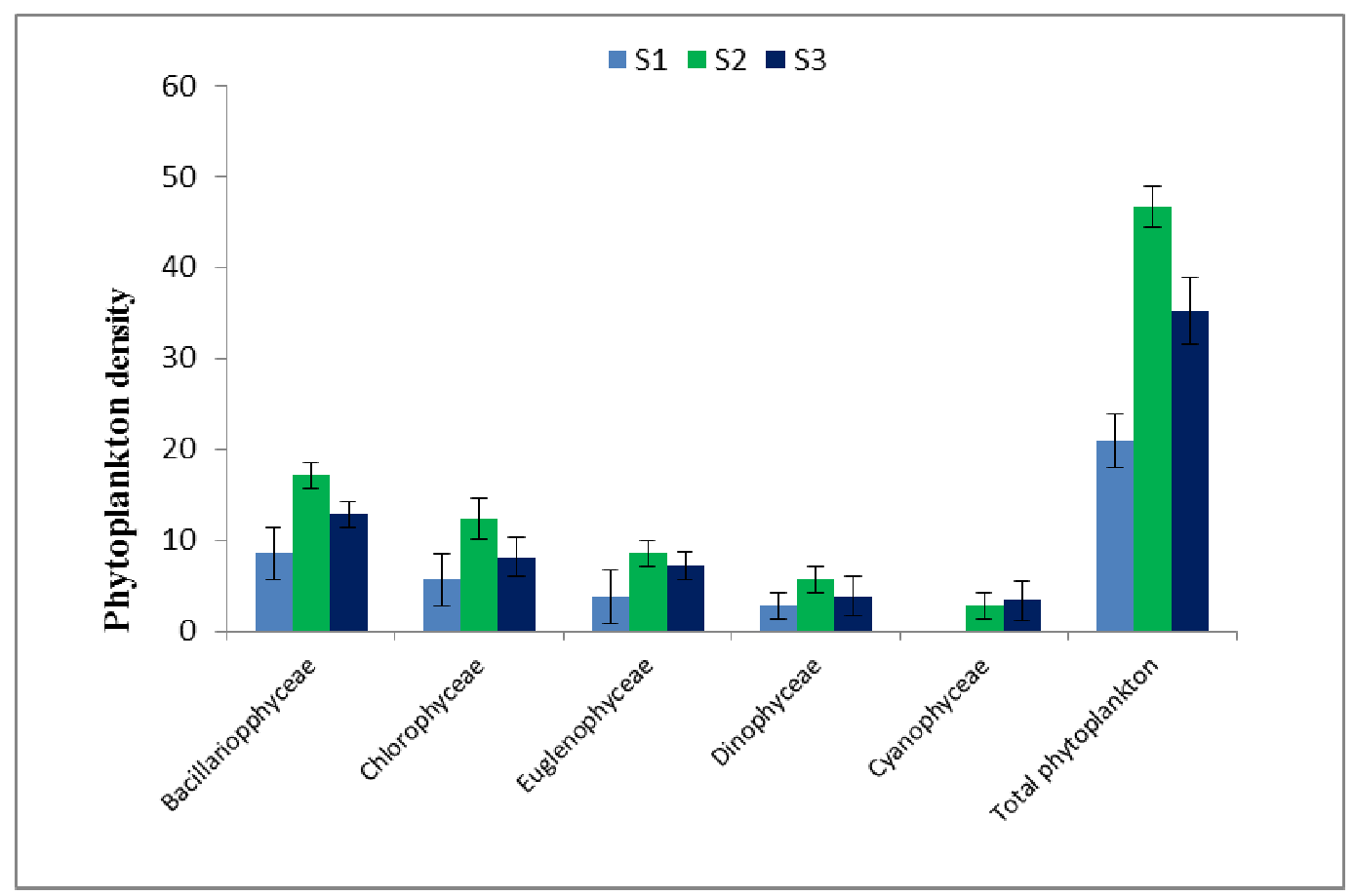

Fig. 2. Major group and density of phytoplankton at different study sites.

Table III. Phytoplankton diversity indices of the Shitalakhya River

\begin{tabular}{lccc}
\hline Station & 1 & 2 & 3 \\
\hline Shannon (H) & 2.313 & 2.998 & 2.792 \\
Simpson (1/D) & 0.895 & 0.937 & 0.935 \\
Margalef & 0.972 & 2.062 & 1.560 \\
Evenness & 0.948 & 0.865 & 0.943 \\
\hline
\end{tabular}

According to Ali et al. (2003), the values of Margalef's index ranging between 1 and 3 indicate moderately polluted water with values less than 1 indicating the heavily polluted environment, while values greater than 3 windows clean water. The Margalef diversity index values varied from 0.97 to 2.06 , during the present study (Table III) which indicates that the system is threatened by pollution, which may be as a result of anthropogenic activities going on within the area. Pielou's evenness index refers to how close in number each species in an environment is. In the present study, the Pielou's evenness index was found to range from 0.86 to 0.94 (Table III); if the evenness index is high (approaching 1), there is no species dominance and vice versa. Pirzan et al. (2008) opined that if the evenness index approaches zero, the species evenness in the community was low, and inversely if the evenness index approaches 1 the species in the community is the same. In the present study, the evenness index approaching 1 
indicates that no species is dominating the Shitalakhya River and meaning that the aquatic ecosystem is still stable.

The present biological investigation stated the spatial variation of physico-chemical parameters and their influences on phytoplankton community of Shitalakhya River with an exploration statistical data output. The density and diversity of the phytoplankton population were higher at $\mathrm{S}_{2}$ with the high value of water temperature, TDS, and nutrients (nitrites, nitrates, phosphate, and silicate) than the other two stations. Increasing urbanization and industrialization pose very serious threats due to the increasing quantity of effluents of all types being added to the Shitalakhya River water may lead to degradation of water and the aquatic community. From this short-term survey on phytoplankton abundance and physico-chemical parameters, it could be concluded that there is an urgent need for additional research for the betterment of water quality and maintaining sustainable production of fish in this river.

\section{Literature Cited}

Ahmed, K.K.U., S.U. Ahamed, M.R.A. Hossain, T. Ahmed and S. Barman, 2003. Quantitative and qualitative assessment of plankton: some ecological aspect and water quality parameters of the river Meghna, Bangladesh. Bangladesh J. Fish. Res., 7(2): 131140.

Ahmed, M.J., A. Ahsan, M.R. Haque, S. Siraj, M.H.R. Bhuiyan, S.C. Bhattacharjee and S. Islam, 2010. Physicochemical assessment of surface and groundwater quality of the greater Chittagong region of Bangladesh. Pak. J. Anal. Environ. Chem., 11(2): 11.

Alam, A., M.G. Mustafa and M.A.K. Azad, 2007. Water and sediment quality and plankton diversity of Posna beel, Tangail. Bangladesh J. Fish., 30: 177-188.

Ali, M., A. Salam, S. Jamshaed, T. Zahara, 2003. Studies on biodiversity in relation to seasonal variations in water of river Indus at Ghazi Ghatt, Punjab Pakistan. Pakistan J. Biol. Sci., 6(21):1840-1844.

Begum, Z.T. and D. Khanam, 2009. Physicochemical aspects and phytoplankton of the river Shitalakhya receiving pharmaceutical effluents. Bangladesh J. Bot., 38(1): 77-85.

Bellinger, E.G. and D.C. Sigee, 2015. Freshwater algae: identification, enumeration and use as bioindicators. John Wiley and Sons.

Bellos, D., T. Sawidis and I. Tsekos, 2004. Nutrient chemistry of river Pinios (Thessalia, Greece). Environ. Int., 30(1): 105-115.

Dash, M.C., 1996. Fundamentals of Ecology, Tata McGraw Hill Publ. Comp. Ltd. New Delhi.

ECR (Environmental Conservation Rules), 1997. Department of Environment, Dhaka, Bangladesh, 212-214.

EPA (Environmental Protection Agency), 1997. Exposure factors handbook. Washington, DC, U.S., Office of Research and Development, National Center for Environmental Assessment.

Esenowo, I.K. and A.A.A. Ugwunba, 2010. Composition and abundance of Macrobenthes in Majidun River Ikorodu Lagos State. Nigeria. Res. J. Biol. Sci., 5(8): 556-560.

Fakayode, S.O., 2005. Impact Assessment of Industrial Effluent on Water Quality of the Receiving Alaro River in Ibadan, Nigeria. Afr. J. Environ. Assess. Manage., 10: 1-13.

Ferdous, Z., S. Akter, M. Hasan, R.A. Begum and R.M. Shahajahan, 2012. Phytoplankton diversity and abundance in relation to pollution levels in the Hazaribagh tannery effluent sewage water of the river Buriganga. Bangladesh J. Zool., 40(1): 121-128. 
Fonge, B.A., P.T. Tabot, C.A. Mange, and C. Mumbang, 2015. Phytoplankton community structure and physico-chemical characteristics of streams flowing through an agroplantation complex in Tiko, Cameroon. J. Ecol. Nat. Environ., 7 (5): 170-179.

Hendley, N.I., 1977. The species diversity index of some in-shore diatoms communities and its use in assessing the degree of pollution insult on parts of the North Coast of Cornwall. In: Cramme, J. (ed.) Fourth Symposium on Recent and Fossil Marine Diatoms, pp: 355-378.

Islam, S.M.D. and M.E. Huda, 2016. Water pollution by industrial effluent and phytoplankton diversity of Shitalakhya River, Bangladesh. J. Sci. Res., 8(2), 191-198.

Kabir, M., M. Kibria, and M.M. Hossain, 2019. Integrated management of water resources of Halda: a unique river of Bangladesh. Geophysical Res. Abstracts (Vol. 21).

Kozak, A., R. Gołdyn, K. Katarzyna and M. Zimmer, 2012. Water quality and phytoplankton of the recreational used Lake Sławskie. Pol. J. Nat. Sci., 27(4): 419-431.

Margalef, D.R., 1958. Information theory in ecology. Gen. Syst., 3: 36-71.

Murshed, M.M., 2012. Shitalakshya River. In Islam, S. and A.A. Jamal (ed.), Banglapedia: National Encyclopedia of Bangladesh (Second Ed.). Asiatic Society of Bangladesh.

Negi, R.K and R. Vishal, 2015. Assessment of Phytoplankton Diversity in Relation to Abiotic Factors of Nainital Lake of Kumaon Himalayas of Uttarakhand State, India. Asian J. Scient. Res., 8(1): 157-164.

Noori, R., M.S. Sabahi, A.R. Karbassi, A. Baghvand and H.T. Zadeh, 2010. Multivariate statistical analysis of surface water quality based on correlations and variations in the data set. Desalination, 260(1-3): 129-136.

Onyema, I.C., 2008. A checklist of phytoplankton species of the Iyagbe lagoon, Lagos. J. Fish. Aquat. Sci., 3(3): 167-175.

Onyema, I.C., O.G. Otudeko and D.I. Nwankwo, 2003. The distribution and composition of plankton around a sewage disposal site at Iddo, Nigeria. J. Scient. Res. Develop., 7: 11-26.

Pielou, E.C., 1977. Mathematical ecology. Wiley, New York, 385 p.

Pirzan A.M. and P.R. dan Pong-Masak, 2008. Hubungan Keragaman Fitoplankton dengan Kualitas Air di Pulau Bauluang, Kabupaten Takalar, Sulawesi Selatan. Biodiversitas, 9(3): 217-221.

Pitchaikani, J.S. and A.P. Lipton, 2016. Nutrients and phytoplankton dynamics in the fishing grounds off Tiruchendur coastal waters, Gulf of Mannar, India. Springer Plus, 5(1): 1405.

Shannon, C.E. and W. Weiner, 1949. The mathematical theory of communication. University of Illinois, Illinois, $125 \mathrm{p}$.

Simpson, E.H., 1949. Measurement of diversity. Nature, 163: 688.

Usman, L.U., 2016. Some Limnological and Biological Aspects of Ajiwa Reservoir, Katsina State, Nigeria. (M.Sc. Dissertation). Department of Biological Sciences, Ahmadu Bello University, Zaria. 112-118.

Wahab, M.A., Z.F. Ahmed, M.S. Haq and M. Begum, 1994. Compatibility of silver carp in the polyculture of cyprinid fishes. Progress. Agric., 5: 221-227.

Wetzel, R.G. and G.E. Likens, 2006. Limnological analysis. Springer-Verlag, New York, 391 p.

Zafar, M., 1986. Study on zooplankton of Satkhira estuary system in the vicinity of aquaculture farms with special reference to penaeid post larvae. M. Sc. Thesis, Institute of Marine Science, University of Chittagong, Chittagong, Bangladesh. 238 p. 